\title{
Arahan Pengembangan Pariwisata Berdasarkan Adaptasi Teori Siklus Hidup Pariwisata di Kabupaten Ponorogo
}

\author{
Gesti Mutiara Dewi dan Ema Umilia \\ Perencanaan Wilayah dan Kota, Fakultas Arsitektur Desain dan Perencanaan, \\ Institut Teknologi Sepuluh Nopember (ITS) \\ e-mail: ema_umilia@urplan.its.ac.id
}

\begin{abstract}
Abstrak-Kabupaten Ponorogo memiliki potensi pariwisata beraneka ragam yakni sebanyak 50 daya tarik wisata yang tersebar di beberapa kecamatan. Dalam pengembangan pariwisata di Kabupaten Ponorogo terkendala oleh beberapa faktor, yakni aksesibilitas, fasilitas, pemasaran, dan jumlah wisatawan. Kondisi tersebut menyebabkan pengembangan obyek wisata di Kabupaten Ponorogo berbeda-beda. Penelitian ini bertujuan untuk menganalisis tahap perkembangan pariwisata di Kabupaten Ponorogo berdasarkan adaptasi teori siklus hidup pariwisata dan merumuskan arahan pengembangan. Penelitian ini menggunakan analisis deskriptif kualitatif untuk mengidentifikasi tipologi pariwisata di Kabupaten Ponorogo, Content Analysis untuk menentukan variabel yang berpengaruh terhadap siklus hidup di Kabupaten Ponorogo, analisis deskriptif kualitatif untuk menganalisis tahap perkembangan pariwisata berdasarkan siklus hidup pariwisata, dan analisis deskriptif untuk merumuskan arahan pengembangan pariwisata di Kabupaten Ponorogo. Dari penelitian ini akan di hasilkan klasifikasi daya tarik wisata di Kabupaten Ponorogo berdasarkan siklus hidup pariwisata dan arahan pengembangan yang sesuai pada masing-masing siklus hidup yang ada.
\end{abstract}

Kata Kunci- Arahan, Pariwisata, Ponorogo, Siklus Hidup Pariwisata.

\section{PENDAHULUAN}

$\mathrm{P}$ ARIWISATA merupakan sektor ekonomi yang berperan penting peningkatan pendapatan. Perkembangan pariwisata di Indonesia setiap tahunnya mengalami peningkatan. Kontribusi pariwisata terhadap produk domestik bruto (PDB) sebesar 4,23\% dari PDB nasional atau senilai Rp. 461,36 trilliun. Hal ini mengindikasikan bahwa sektor pariwisata dapat membangun perekonomian Indonesia [1].

Salah satu wilayah di Jawa Timur yang memiliki potensi pariwisata yang beragam adalah Kabupaten Ponorogo. Potensi pariwisata kabupaten Ponorogo yang beraneka ragam merupakan kekayaan yang sangat perlu di lestarikan dan di kembangkan. Perkembangan pariwisata di Kabupaten Ponorogo mengalami peningkatan dalam rentang waktu 2011-2015. Jumlah wisatawan mengalami peningkatan sekitar 2\% disetiap tahunnya [2].

Berdasarkan RTRW Kabupaten Ponorogo Tahun 20122032, tujuan penaatan ruang Kabupaten Ponorogo yaitu "Mewujudkan ruang wilayah yang produktif berbasis pertanian dan pariwisata unggulan agar berwawasan lingkungan hidup di Jawa Timur”. Adapun kebijakan dalam penataan ruang yang berkaitan dengan pariwisata yaitu peningkatan potensi alam dan sejarah dalam mewujudkan pengembangan pariwisata unggulan serta pengembangan kawasan dan event wisata unggulan [3].
Daya tarik wisata di Kabupaten Ponorogo antara lain wisata alam, wisata seni dan sejarah, wisata religi dan sejarah, serta wisata buatan. Terdapat sejumlah 50 daya tarik wisata (DTW) yang terdiri dari 31 wisata alam, 9 wisata religi dan sejarah, serta 10 wisata buatan [2]. Dengan adanya berbagai potensi pariwisata, sektor pariwisata menjadi salah satu prioritas pembangunan di Kabupaten Ponorogo. Berdasarkan RPJMD Kabupaten Ponorogo 2016-2021, pada tahun 2019 pariwisata menjadi fokusan pembangunan di Kabupaten Ponorogo. Sektor pariwisata merupakan salah satu sektor unggulan yang berperan dalam mendukung laju pembangunan Kabupaten Ponorogo [4].

Namun pengembangan pariwisata di Kabupaten Ponorogo tidak merata, terdapat daya tarik wisata yang berkembang dan tidak berkembang. Salah satu daya tarik wisata yang sudah berkembang dan paling diminati oleh wisatawan adalah wisata alam Telaga Ngebel. Selama tahun 2015, tempat wisata yang banyak dikunjungi adalah Telaga Ngebel dengan jumlah wisatawan 76.464 orang. Sedangkan daya tarik wisata yang paling sedikit dikunjungi oleh wisatawan adalah Air Terjun Pletuk dengan jumlah wisatawan 1.170 orang. Selain itu, juga terdapat obyek wisata yang sudah tidak beroperasi dan beralih fungsi untuk kegiatan non pariwisata yakni, Hutan Wisata Kucur dan Kintamani Water Park. Hutan Wisata Kucur telah beralih fungsi sebagai rest area dan Kintamani Water Park yang berailh fungsi sebagai rumah makan [2].

Terjadinya ketimpangan dalam pengembangan pariwisata di Kabupaten Ponorogo terkendala oleh beberapa faktor, diantaranya keterbatasan sarana dan prasarana serta masalah pemasaran[5]. Kondisi fasilitas yang ada di sejumlah obyek wisata juga kurang baik. Selain itu, akses jalan yang sulit juga menjadi faktor pertimbangan wisatawan untuk datang ke Kabupaten Ponorogo. Berdasarkan Laporan Akhir RIPPDA Tahun 2016, daya tarik wisata yang belum berkembang karena kurangnya upaya promosi, keterbatasan infrastruktur, aksesibilitas yang sulit, dan ketersediaan fasilitas yang kurang [6].

Pada dasarnya pengembangan wisata mengikuti alur atau siklus hidup yang dikenal dengan siklus hidup pariwisata atau Tourist Area Life Cycle (TALC). Siklus hidup pariwisata atau Tourist Area Life Cycle (TALC) merupakan sebuah konsep yang digunakan untuk menggambarkan dan memahami proses pengembangan pariwisata. Dalam teori siklus hidup pariwisata atau Tourist Area Life Cycle (TALC) dijelaskan bahwa pada dasarnya pariwisata mengalami 7 (tujuh) fase perkembangan, yaitu exploration, involvement phase, development phase, consolidation phase, stagnation phase, decline phase, dan rejuvenation phase [7]. 
Berdasarkan kondisi dan permasalahan tersebut maka perlu analisis siklus hidup pariwisata dan perumusan arahan untuk pengembangan pariwisata di Kabupaten Ponorogo. Arahan pengembangan ini nantinya digunakan untuk mengoptimalkan pariwisata di Kabupaten Ponorog sehingga dapat berkembang.

\section{METODE PENELITIAN}

\section{A. Jenis dan Pendekatan Penelitian}

Pendekatan yang digunakan dalam penelitian ini adalah pendekatan rasionalistik. Pendekatan rasionalistik bersifat pemaknaan terhadap realitas empiris berdasarkan pengetahuan teoritis dan berangkat dari grounded theory atau teori dasar sebagai landasan teorinya.Dalam penelitian ini dikumpulkan teori-teori yang berkaitan dengan pariwisata dan siklus hidup pariwisata sebagai dasar penelitian.Jenis penelitian dalam penelitian ini adalah deskripti kualitatif.

\section{B. Variabel Penelitian}

Variabel penelitian yang digunakan untuk mengidentifikasi tipologi pariwisata di Kabupaten Ponorogo antara lain something to see, something to do, something to buy, fasilitas utama, fasilitas pelengkap, fasilitas penunjang, kondisi jalan, jenis kendaraan, ketersediaan transportas umum, jaringan listrik, jaringan air bersih, persampahan, pengelola wisata, promosi, tren jumlah pengunjung, dan investasi.

Variabel penelitian yang digunakan untuk penentuan tahap perkembangan pariwisata berdasarkan siklus hidup pariwisata di Kabupaten Ponorogo antara lain something to see, something to do, something to buy, fasilitas utama, fasilitas penunjang, kondisi jalan, jenis kendaraan, jaringan air bersih, persampahan, pengelola wisata, promosi, dan tren jumlah pengunjung.

\section{Mengidentifikasi Tipologi Pariwisata di Kabupaten Ponorogo}

Dalam penentuan tipologi pariwisata di Kabupaten Ponorogo pada penelitian ini menggunakan teknik analisis deskriptif kualitatif. Analisis deskriptif kualitatif di lakukan dengan mengidentifikasi karakteristik daya tarik wisata berdasarkan kondisi eksisitingnya yang kemudian akan di kelompokkan berdasarkan jenis wisata, sehingga akan terbentuk tipologi pariwisata di Kabupaten Ponorogo.

D. Menentukan Variabel yang Berpengaruh Terhadap Siklus Hidup Pariwisata di Kabupaten Ponorogo

Teknik analisis yang digunakan dalam menentukan variabel yang berpengaruh terhadap siklus hidup pariwisata di Kabupaten Ponorogo adalah Content Analysis (CA). Dalam penelitian ini, content analysis dilakukan untuk mengkaji informasi dari hasil wawancara dengan stakeholder terkait, yakni Bappeda Kabupaten Ponorogo, Dinas Pariwisata Kabupaten Ponorogo, dan Pokdarwis Kabupaten Ponorogo. Melalui content analysis, akan didapatkan kesimpulan terkait variabel yang berpengaruh terhadap perkembangan pariwisata berdasarkan siklus hidup pariwisata di Kabupaten Ponorogo.

\section{E. Mengidentifikasi Tahapan Perkembangan Pariwisata Berdasarkan Siklus Hidup Pariwisata di Kabupaten Ponorogo}

Teknik analisis yang digunakan dalam mengidentifikasi tahapan perkembangan pariwisata berdasarkan siklus hidup pariwisata di Kabupaten Ponorogo menggunakan analisis deskriptif kualitatif. Dalam melakukan analisis dilakukan komparasi antara kondisi eksisting dengan variabel yang berpengaruh terhadap siklus hidup pariwisata di Kabupaten Ponorogo. Daya tarik wisata yang terdapat di Kabupaten Ponorogo akan di kelompokkan berdasarkan tahap perkembangannya.

\section{F. Arahan Pengembangan Pariwisata Berdasarkan Siklus Hidup Pariwisata di Kabupaten Ponorogo}

Dalam penentuan arahan pengembangan pariwisata berdasarkan siklus hidup pariwisata di Kabupaten Ponorogo menggunakan analisis deskriptif kualitatif. Dalam melakukan metode analisis ini dilakukan dengan cara mengkomparasikan antara hasil analisis tahapan perkembangan, teori, best practice, dan kondisi eksisting. Perumusan arahan pengembangan pariwisata dalam penelitian ini dilakukan pada setiap tahapan perkembangan berdasarkan siklus hidup pariwisata di Kabupaten Ponorogo

\section{HASIL DAN PEMBAHASAN}

\section{A. Identifikasi Tipologi Pariwisata di Kabupaten Ponorogo}

Berdasarkan analisis di dapatkan hasil bahwa di tinjau dari daya tarik wisatanya pariwisata di Kabupaten Ponorogo terbagi menjadi 3 tipologi, yakni:

\section{Daya Tarik Wisata Alam}

Daya tarik wisata alam di Kabupaten Ponorogo sebanyak 31 daya tarik wisata yang tersebar di 12 kecamatan.

$$
\text { Tabel } 1
$$

Daya Tarik Wisata Alam

\begin{tabular}{ll} 
& Daya Tarik Wisata Alam \\
\hline \hline No. & \multicolumn{1}{c}{ Obyek Wisata } \\
\hline 1 & Telaga Ngebel \\
2 & Sumber Air Panas Tirta Husada \\
3 & Air Terjun Selorejo \\
4 & Air Terjun Sundan Widodaren \\
5 & Air Terjun Sunggah \\
6 & Watu Semaur \\
7 & Tumpak Pare \\
8 & Kedung Gamping \\
9 & Air Terjun Jurang Gandul \\
10 & Air Terjun Coban Lawe \\
11 & Tanah Goyang \\
12 & Air Terjun Pletuk \\
13 & Gunung Bedes \\
14 & Air Terjun Coban Pelangi \\
15 & Air Terjun Jurug Klenteng \\
16 & Air Terjun Coban Kokok \\
17 & Hutan Wisata Kucur \\
18 & Gunung Masjid \\
19 & Gunung Beruk \\
20 & Air Terjun Kedung Mimang \\
21 & Air Terjun Widodaren \\
22 & Air Terjun Plasur \\
23 & Goa Lowo \\
24 & Bukit Cumbri \\
25 & Kedung Kenthus \\
26 & Air Terjun Setapak \\
27 & Air Terjun Mertapan \\
28 & Sendang Bulus \\
29 & Beji Tunggul Wulung \\
30 & Gunung Pringgitan \\
31 & Gunung Gajah \\
\hline \hline &
\end{tabular}




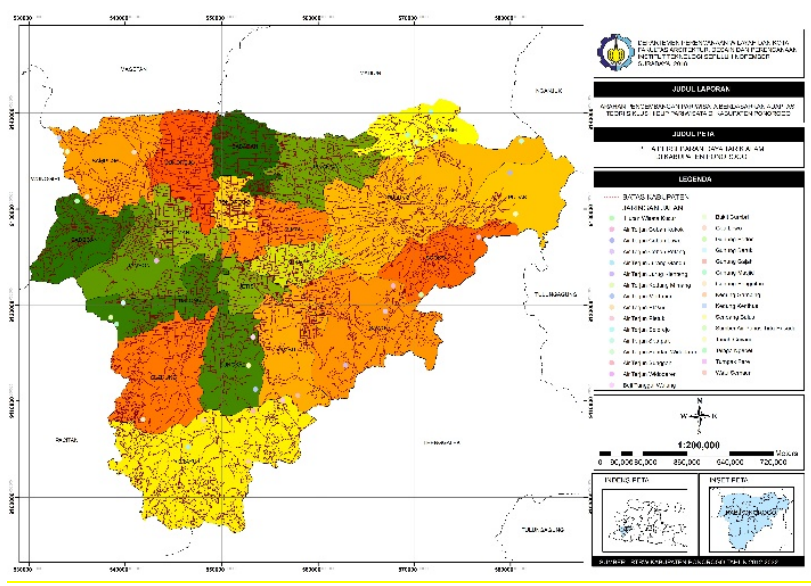

Gambar 1. Persebaran Daya Tarik Wisata Alam di Kabupaten Ponorogo

2. Daya Tarik Wisata Religi dan Sejarah

Daya tarik wisata religi dan sejarah di Kabupaten Ponorogo sebanyak 9 daya tarik wisata yang tersebar di 7 kecamatan.

Tabel 2

Daya Tarik Wisata Religi dan Sejarah

\begin{tabular}{cl}
\hline \hline No. & \multicolumn{1}{c}{ Obyek Wisata } \\
\hline 1 & Masjid Tegalsari \\
2 & Masjid Baiturrohman \\
3 & Masjid Agung Kota Lama \\
4 & Makam Batoro Katong \\
5 & Komplek Pesarean Astana Srandil \\
6 & Beji Sirah Keteng \\
7 & Situs Watu Dukun \\
8 & Sendang Tirtto Waluyo Jatiningsih \\
9 & Komplek Pesarean Joyonegoro \\
\hline \hline
\end{tabular}

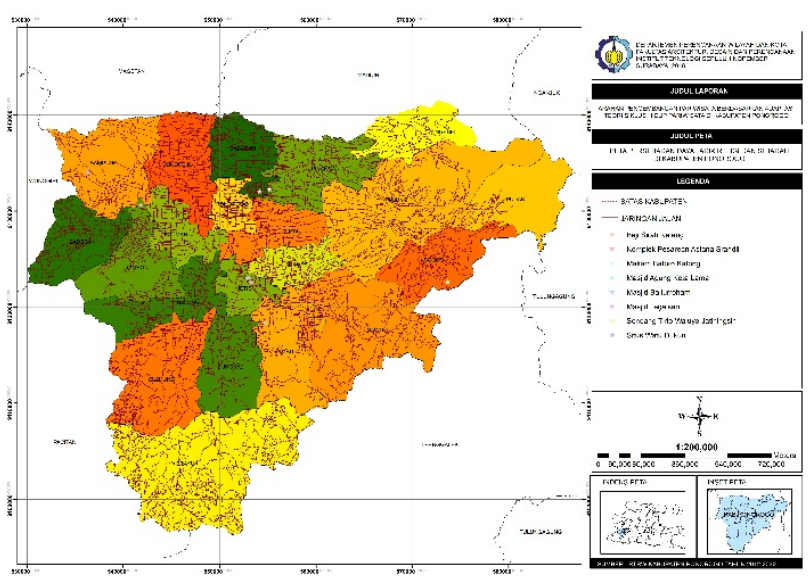

Gambar 2. Persebaran Daya Tarik Wisata Religi dan Sejarah di Kabupaten Ponorogo

\section{Daya Tarik Wisata Buatan}

Daya tarik wisata buatan di Kabupaten Ponorogo sebanyak 10 daya tarik wisata yang tersebar di 4 kecamatan.

Tabel 3

Daya Tarik Wisata Buatan

\begin{tabular}{cl}
\hline \hline No. & \multicolumn{1}{c}{ Obyek Wisata } \\
\hline 1 & Kolam Renang Tirto Joyo \\
2 & Taman Sukowati \\
3 & Taman Kota \\
4 & Kolam Renang Tirto Menggolo \\
5 & Taman Wisata Ngembag \\
6 & Kintamani Water Park \\
7 & Pemancingan Betri \\
8 & Taman Kelinci \\
9 & Brilliant Water Park \\
10 & Gita Water Park \\
\hline \hline
\end{tabular}

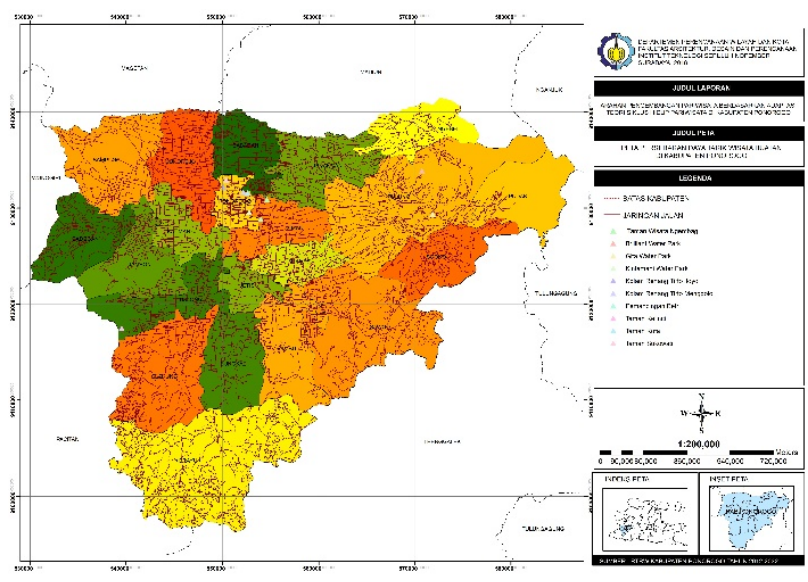

Gambar 3. Persebaran Daya Tarik Wisata Buatan di Kabupaten Ponorogo

B. Menentukan Variabel yang Berpengaruh Terhadap Siklus Hidup Pariwisata di Kabupaten Ponorogo

Berdasarkan proses coding hasil wawancara, berbagai pendapat stakeholder terkait variabel penelitian dapat disimpulakn sebagai berikut:

Tabel 4

Hasil Coding Wawancara

\begin{tabular}{|c|c|c|c|c|c|c|c|}
\hline \multirow{2}{*}{ Indikator } & \multirow{2}{*}{ Variabel } & \multicolumn{2}{|c|}{ "G1 } & \multicolumn{2}{|c|}{ 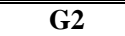 } & \multicolumn{2}{|c|}{ P1 } \\
\hline & & B & TB & B & TB & $\mathbf{B}$ & TB \\
\hline \multirow{3}{*}{$\begin{array}{l}\text { Daya } \\
\text { wisata }\end{array}$} & Something to see & $\sqrt{ }$ & & $\sqrt{ }$ & & $\sqrt{ }$ & \\
\hline & Something to do & $\sqrt{ }$ & & $\sqrt{ }$ & & $\sqrt{ }$ & \\
\hline & Something to buy & $\sqrt{ }$ & & $\sqrt{ }$ & & $\sqrt{ }$ & \\
\hline \multirow[t]{3}{*}{ Fasilitas } & Fasilitas utama & $\sqrt{ }$ & & $\sqrt{ }$ & & $\sqrt{ }$ & \\
\hline & $\begin{array}{l}\text { Fasilitas } \\
\text { pendukung }\end{array}$ & $\sqrt{ }$ & & & $\sqrt{ }$ & & $\sqrt{ }$ \\
\hline & $\begin{array}{l}\text { Fasilitas } \\
\text { penunjang }\end{array}$ & $\sqrt{ }$ & & $\sqrt{ }$ & & $\sqrt{ }$ & \\
\hline \multirow[t]{3}{*}{ Aksesibilitas } & Kondisi jalan & $\sqrt{ }$ & & $\sqrt{ }$ & & $\sqrt{ }$ & \\
\hline & Jenis kendaraan & $\sqrt{ }$ & & $\sqrt{ }$ & & $\sqrt{ }$ & \\
\hline & $\begin{array}{l}\text { Ketersediaan } \\
\text { transportasi } \\
\text { umum }\end{array}$ & & $\sqrt{ }$ & & $\sqrt{ }$ & & $\sqrt{ }$ \\
\hline \multirow[t]{3}{*}{ Prasarana } & Jaringan listrik & & & & & & \\
\hline & $\begin{array}{l}\text { Jaringan air } \\
\text { bersih }\end{array}$ & $\sqrt{ }$ & & $\sqrt{ }$ & & $\sqrt{ }$ & \\
\hline & Persampahan & $\sqrt{ }$ & & $\sqrt{ }$ & & $\sqrt{ }$ & \\
\hline Kelembagaan & Pengelola wisata & $\sqrt{ }$ & & $\sqrt{ }$ & & $\sqrt{ }$ & \\
\hline Pemasaran & Promosi & $\sqrt{ }$ & & $\sqrt{ }$ & & $\sqrt{ }$ & \\
\hline $\begin{array}{l}\text { Jumlah } \\
\text { pengunjung }\end{array}$ & $\begin{array}{l}\text { Tren jumlah } \\
\text { pengunjung }\end{array}$ & $\sqrt{ }$ & & $\sqrt{ }$ & & $\sqrt{ }$ & \\
\hline Investasi & Investor & & $\sqrt{ }$ & & $\sqrt{ }$ & & $\sqrt{ }$ \\
\hline
\end{tabular}

\section{Keterangan:}

\section{B : Berpengaruh TB: Tidak Berpengaruh}

Berdasarkan hasil content analysis di dapatkan variabelvariabel yang berpengaruh terhadap siklus hidup pariwisata di Kabupaten Ponorogo sebagai berikut.

Tabel 5

Hasil Variabel Yang Berpengaruh

\begin{tabular}{clll}
\hline \hline No. & \multicolumn{1}{c}{ Indikator } & \multicolumn{2}{c}{ Variabel } \\
\hline 1. & Daya tarik wisata & 1. & Something to see \\
& & 2. & Something to do \\
& & 3. & Something to buy \\
2. & Fasilitas & 4. & Fasilitas utama \\
& & 5. & Fasilitas penunjang \\
3. & Aksesibilitas & 6. & Kondisi jalan \\
& & 7. & Jenis kendaraan \\
4. & Prasarana & 8. & Jaringan air bersih \\
& & 9. & Persampahan \\
5. & Kelembagaan & 10. & Pengelola wisata \\
6. & Pemasaran & 11. & Promosi \\
7. & Jumlah pengunjung & 12. & Tren jumlah pengunjung \\
\hline \hline
\end{tabular}




\section{Mengidentifikasi Tahapan Perkembangan Pariwisata Berdasarkan Siklus Hidup Pariwisata di Kabupaten Ponorogo}

Berdasarkan hasil analisis, pariwisata di Kabupaten Ponorogo terbagi menjadi 6 tahapan. Berikut merupakan pengelompokan pariwisata berdasarkan siklus hidup pariwisata di Kabupaten Ponorogo.

Tabel 6

Klasifikasi Pariwisata Berdasarkan Siklus Hidup Pariwisata di Kabupaten Ponorogo

\begin{tabular}{|c|c|c|c|}
\hline Tahapan & Daya tarik alam & $\begin{array}{c}\text { Daya tarik religi } \\
\text { dan sejarah }\end{array}$ & $\begin{array}{c}\text { Daya tarik } \\
\text { buatan }\end{array}$ \\
\hline $\begin{array}{l}\text { Exploration } \\
\text { phase }\end{array}$ & $\begin{array}{ll}\text { 1. } & \text { Bukit Cumbri } \\
\text { 2. Gunung Gajah } \\
\text { 3. Air Terjun } \\
\text { Setapak } \\
\text { 4. Air Terjun } \\
\text { Plasur } \\
\text { 5. Kedung } \\
\text { Kenthus } \\
\text { 6. Watu Semaur }\end{array}$ & - & - \\
\hline $\begin{array}{l}\text { Involvement } \\
\text { phase }\end{array}$ & $\begin{array}{l}\text { 1. Tanah Goyang } \\
\text { 2. Tumpak Pare } \\
\text { 3. Gunung Bedes } \\
\text { 4. Air Terjun } \\
\text { Jurang Gandul } \\
\text { 5. Air Terjun } \\
\text { Coban Pelangi } \\
\text { 6. Air Terjun } \\
\text { Jurug Klenteng } \\
\text { 7. Air Terjun } \\
\text { Coban Kokok } \\
\text { 8. Gunung Masjid } \\
\text { 9. Gunung } \\
\text { Pringgitan } \\
\text { 10. Air Terjun } \\
\text { Sundan } \\
\text { Widodaren } \\
\text { 11. Air Terjun } \\
\text { Kedung } \\
\text { Mimang } \\
\text { 12. Air Terjun } \\
\text { Mertapan } \\
\text { 13. Kedung } \\
\text { Gamping } \\
\text { 14. Air Terjun } \\
\text { Widodaren } \\
\text { 15. Air Terjun } \\
\text { Coban Lawe } \\
\text { 16. Goa Lowo } \\
\text { 17. Air terjun } \\
\text { Sunggah } \\
\text { 18. Air Terjun } \\
\text { Selorejo }\end{array}$ & $\begin{array}{l}\text { 1. Komplek } \\
\text { Pesarean Astana } \\
\text { Srandil } \\
\text { 2. Komplek } \\
\text { Pesarean } \\
\text { Joyonegoro } \\
\text { 3. Sendang Tirto } \\
\text { Waluyo } \\
\text { Jatiningsih } \\
\text { 4. Situs Watu } \\
\text { Dukun } \\
\text { 5. Masjid } \\
\text { Baiturrohman } \\
\text { 6. Masjid Agung } \\
\text { Kota Lama } \\
\text { 7. Beji SIrah Keteng }\end{array}$ & $\begin{array}{l}\text { 1. Taman } \\
\text { Kelinci }\end{array}$ \\
\hline $\begin{array}{l}\text { Development } \\
\text { phase }\end{array}$ & $\begin{array}{l}\text { 1. Gunung Beruk } \\
\text { 2. Beji Tunggul } \\
\text { Wulung } \\
\text { 3. Sumber } \\
\begin{array}{l}\text { Panas Air } \\
\text { Husada }\end{array}\end{array}$ & $\begin{array}{l}\text { 1. Masjid Tegalsari } \\
\text { 2. Makam Batoro } \\
\text { Katong }\end{array}$ & $\begin{array}{l}\text { 1. Taman } \\
\text { Sukowati } \\
\text { 2. Taman } \\
\text { Wisata } \\
\text { Ngembag }\end{array}$ \\
\hline $\begin{array}{l}\text { Consolidatio } \\
n \text { phase }\end{array}$ & $\begin{array}{l}\text { 1. Telaga Ngebel } \\
\text { 2. Air Terjun Pletuk }\end{array}$ & - & $\begin{array}{l}\text { 1. Kolam } \\
\text { Renang } \\
\text { Tirto Joyo } \\
\text { 2. Taman Kota } \\
\text { 3. Kolam } \\
\text { Renang } \\
\text { Tirto } \\
\text { Menggolo } \\
\text { 4. Pemancinga } \\
\text { n Betri } \\
\text { 5. Gita Water } \\
\text { Park } \\
\text { 6. Brilliant } \\
\text { Water Park }\end{array}$ \\
\hline
\end{tabular}

\begin{tabular}{|c|c|c|c|}
\hline Tahapan & Daya tarik alam & $\begin{array}{c}\text { Daya tarik religi } \\
\text { dan sejarah }\end{array}$ & $\begin{array}{c}\text { Daya tarik } \\
\text { buatan }\end{array}$ \\
\hline $\begin{array}{l}\text { Decline } \\
\text { phase }\end{array}$ & $\begin{array}{l}\text { 1. Hutan } \\
\text { Kucur }\end{array}$ & - & $\begin{array}{l}\text { 1. Kintamani } \\
\text { Water Park }\end{array}$ \\
\hline $\begin{array}{l}\text { Rejuvenation } \\
\text { phase }\end{array}$ & 1. Sendang Bulus & - & - \\
\hline
\end{tabular}

Berikut penjelasan dari masing-masing tahap perkembangan obyek wisata di Kabupaten Ponorogo:

\section{Exploration Phase}

Obyek wisata yang berada pada exploration phase terdiri dari 6 obyek wisata alam. Mayoritas obyek wisata yang berada pada tahap ini masih berfokus pada pengembangan daya tarik wisata yang masih alami. Atraksi wisata yang ada juga masih berfokus pada atraksi wisata yang alami. Pada tahap ini, juga belum tersedia berbagai fasilitas. Maka dari itu, jumlah pengunjung yang ada juga masih sedikit. Hal tersebut juga disebabkan karena belum adanya pengelola obyek wisata. Sehingga, kegiatan promosi untuk memperkenalkan obyek wisata juga belum ada.

\section{Involvement Phase}

Obyek wisata yang berada pada development phase terdiri dari 18 wisata alam, 7 wisata religi dan sejarah, serta 1 wisata buatan. Obyek wisata yang termasuk dalam tahap ini sudah ada yang mengelola, sehingga sudah mulai ada upaya untuk melakukan promosi obyek wisata ke masyarakat. Selain itu, berbagai fasilitas juga mulai disediakan oleh pengelola. Kecenderungan obyek wisata di Kabupaten Ponorogo yang termasuk dalam exploration phase, sudah memiliki fasilitas penunjang berupa tempat parkir dan tempat makan. Sehingga, dengan mulai adanya fasilitas dan adanyan kegiatan promosi, jumlah pengunjung menunjukkan ada sedikit peninngkatan dari sebelumnya.

\section{Development Phase}

Obyek wisata yang berada pada involvement phase terdiri dari 3 wisata alam, 2 wisata religi dan sejarah, serta 2 wisata buatan. Obyek wisata yang termasuk dalam tahap ini sudah ada yang mengelola, yakni masyarakat lokal dan Pemerintah Daerah. Ketersediaan fasilitas penunjang juga semakin bertambah, seperti tempat aprkir, tempat makan, dan toilet. Fasilitas utama untuk mendukung atraksi wisata yang alami juga mulai disediakan, seperti kolam renang, rumah pohon atau gardu pandang, dan arena bermain. Selain itu, kecenderungan obyek wisata yang berada pada tahap ini juga memiliki aksesibilitas mudah dengan jalan yang sudah berasapal dan dapat dijangkau dengan motor dan mobil. Kegiatan promosi yang dilakukan oleh pengelola obyek wisata juga semakin intensif, melalui media sosial dan banner. Maka dari itu, jumlah pengunjung meningkat terus.

\section{Consolidation Phase}

Obyek wisata yang berada pada consolidation phase terdiri dari 2 wisata alam dan 6 wisata buatan. Fasilitas utama untuk mendukung atraksi wisata mulai beragam, seperti kolam renang, perahu, kolam pemancingan, arena bermain, dan arena olahraga. Ketersediaan fasilitas penunjang juga sudah lengkap, dari adanya tempat parkir, tempat makan, toilet, mushola, tempat penitipan barang, toko oleh-oleh, serta meeting room. Pengelola obyek wisata juga semakin intensif dalam melakukan kegiatan promosi, sehingga jumlah pengunjung semakin bertambah. Obyek wisata yang berada pada tahap ini, juga sudah mempunyai aksesibilitas yang mudah dan dapat dijangkau oleh motor maupun mobil.

\section{Decline Phase}

Obyek wisata yang berada pada decline phase adalah Hutan Wisata Kucur dan Kintamani Water Park. Kedua 
obyek wisata tersebut mengalami penurunan karena jumlah pengunjung yang semakin menurun. Selain itu, fasilitas yang terdapat di obyek wisata sudah beralih fungsi untuk kegiatan non-pariwisata. Obyek wisata Hutan Kucur sudah berlaih fungsi menjadi rest area karena letaknya yang strategis di pinggir jalan. Sedangkan, Kintamani Water Park kini sudah beralih fungsi menjadi tempat makan, kegiatan wisatanya sudah tidak beroperasi lagi.

\section{Rejuvenation Phase}

Obyek wisata yang berada pada rejuvenation phase adalah Sendang Bulus. Obyek wisata ini mengalami penurunan jumlah pengunjung ketika daya tarik utama yakni hewan bulus (kura-kura) sudah hilang. Namun, kini pengelola memperbaiki fasilitas seperti gazebo yang terdapat di obyek wisata Sendang Bulus. Selain itu, pengelola obyek wisata menambah atraksi wisata baru, seperti bermain sepeda bebek air dan pemancingan ikan. Seiring dengan perbaikan tersebut, kegiatan promosi juga mulai dilakukan kembali, dan kini jumlah pengunjung di Sendang Bulus mengalami peningkatan sedikit daripada sebelumnya.

\section{Arahan Pengembangan Pariwisata Berdasarkan Siklus Hidup Pariwisata di Kabupaten Ponorogo}

Dari hasil identifikasi tahapan perkembangan pariwisata di Kabupaten Ponorogo berdasarkan siklus hidup pariwisata di hasilkan 6 tahapan perkembangan yang terbentuk di Kabupaten Ponorogo. Berikut arahan pengembangan yang sesuai pada masing-masing tahapan perkembangan.

1. Arahan pengembangan pada exploration phase yakni sebagai berikut:

- Mengembangkan potensi alam dengan menambah atraksi wisata seperti outbond, camping, berfoto pada spot unik untuk menarik lebih banyak pengunjung, yakni di Bukit Cumbri, Gunung Gajah, Air Terjun setapak, Air Terjun Plasur, Kedung Kenthus, dan Watu Semaur.

- Memberdayakan masyarakat lokal untuk mengelola obyek wisata, yakni obyek wisata Bukit Cumbri, Gunung Gajah, Air Terjun setapak, Air Terjun Plasur, Kedung Kenthus, dan Watu Semaur.

- Memperbaiki aksesibilitas menuju obyek wisata dengan melebarkan jalan dan memperbaiki kondisi jalan yang rusak, yakni di Bukit Cumbri, Gunung Gajah, Air Terjun Setapak, dan Air Terjun Plasur.

- Menyediakan fasilitas, baik fasilitas utama, fasilitas pendukung, serta fasilitas penunjang untuk memenuhi kebutuhan pengunjung ketika berwisata, yakni di Bukit Cumbri, Gunung Gajah, Air Terjun setapak, Air Terjun Plasur, Kedung Kenthus, dan Watu Semaur.

2. Arahan pengembangan pada involvement phase yakni sebagai berikut:

- Menambah ketersediaan fasilitas penunjang seperti toilet dan mushola untuk memenuhi kebutuhan pengunjung, yakni di obyek wisata Tanah Goyang, Tumpak Pare, Gunung Masjid, Air Terjun Widodaren, Air Terjun Kedung Mimang, Air Terjun Mertapan, Kedung Gamping, Air Terjun Sundan Widodaren Air Terjun Coban Lawe, Air Terjun Sunggah, Taman Kelinci, Air Terjun Selorejo, Gunung Bedes, Air Terjun Jurang Gandul, Air Terjun Coban Pelangi, Air Terjun Jurug Klenteng, Air Terjun Coban, Gunung Pringgitan, Komplek Pesarean Astana Srandil, Komplek Pesarean Joyonegoro, Sendang Tirto Waluyo Jatiningsih, Goa Lowo, Situs Watu Dukun, Masjid Baiturrohman, Masjid Agung Kota Lama, dan Beji Sirah Keteng.
- Meningkatkan kegiatan promosi melalui media seperti brosur, radio, koran, banner, serta bekerjasama dengan travel agent untuk menarik wisatawan, yakni pada obyek wisata Tanah Goyang, Tumpak Pare, Gunung Masjid, Air Terjun Widodaren, Air Terjun Kedung Mimang, Air Terjun Mertapan, Kedung Gamping, Air Terjun Sundan Widodaren Air Terjun Coban Lawe, Air Terjun Sunggah, Taman Kelinci, dan Air Terjun Selorejo.

- Melakukan upaya promosi untuk memperkenalkan obyek wisata kepada masyarakat luar melalui iklan maupun brosur, yakni pada obyek wisata Gunung Bedes, Air Terjun Jurang Gandul, Air Terjun Coban Pelangi, Air Terjun Jurug Klenteng, Air Terjun Coban, Gunung Pringgitan, Komplek Pesarean Astana Srandil, Komplek Pesarean Joyonegoro, Sendang Tirto Waluyo Jatiningsih, Goa Lowo, Situs Watu Dukun, Masjid Baiturrohman, Masjid Agung Kota Lama, dan Beji Sirah Keteng.

3. Arahan pengembangan pada development phase yakni sebagai berikut:

Menjalin kerjasama dengan investor untuk membantu pengembangan obyek wisata, terutama untuk penyediaan fasilitas dan perbaikan aksesibilitas, yakni pada obyek wisata Gunung Beruk, Beji Tunggul Wulung, Masjid Tegalsari, Makam Batoro Katong, Taman Sukowati, dan Taman Wisata Ngembag.

4. Arahan pengembangan pada consolidation phase yakni sebagai berikut:

- Pelestarian kondisi lingkungan dalam pengembangan dan pengelolaan obyek wisata agar tidak menimbulkan dampak negative terhadap lingkungan sekitar, yakni di Telaga Ngebel, Air Terjun Pletuk, Kolam Renang Tirto Joyo, Taman Kota, Kolam Renang Tirto Menggolo, Pemancingan Betri, Gita water Park, dan Brilliant Water Park.

- Penambahan atraksi wisata yang lebih beragam dan penyelenggaraan event pada waktu tertentu untuk terus menarik pengunjung, yakni di Kolam Renang Tirto Joyo, Taman Kota, Kolam Renang Tirto Menggolo, Pemancingan Betri, Gita Water Park, dan Brilliant Water Park.

5. Arahan pengembangan pada decline phase yakni sebagai berikut:

Memperbaiki fasilitas terutama fasilitas utama yang sudah beralih fungsi untuk kegiatan non pariwisata agar dapat berfungsi lagi sebagai fasilitas pariwisata yakni di Hutan Wisata Kucur dan Kintamani Water Park.

6. Arahan pengembangan pada rejuvenation phase yakni sebagai berikut:

Perbaikan dan pengadaan atraksi wisata baru seperti memancing dan bermain sepeda bebek air untuk menghidupkan kembali kegiatan wisata di Sedang Bulus.

\section{KESIMPULAN}

Berdasarkan daya tarik wisatanya, dari 50 daya tarik wisata yang ada di Kabupaten Ponorogo terbagi menjadi 3 tipologi yakni 31 daya tarik wisata alam, 9 daya tarik wisata religi dan sejarah, serta 10 daya tarik buatan.

Terdapat 12 variabel yang berpengaruh terhadap siklus hidup pariwisata di Kabupaten Ponorogo, yakni something to see, something to do, something to buy, fasilitas utama, fasilitas penunjang, kondisi jalan, jenis kendaraan, jaringan air bersih, persampahan, pengelola wisata, promosi, dan tren jumlah pengunjung. 
Berdasarkan siklus hidup pariwisata, daya tarik wisata di Kabupaten Ponorogo terbagi menjadi 6 tahapan perkembangan, yakni exploration phase, involvement phase, development phase, consolidation phase, dan decline phase, dan rejuvenation phase.

Arahan yang dihasilkan adalah sebagai berikut:

- Pada exploration phase memiliki arahan mengembangkan potensi alam dan atraksi wisata, memberdayakan masyarakat lokal untuk mngelola, memperbaiki aksesibilitas, serta menyediakan berbagai fasilitas utama, pendukung, dan penunjang.

- Pada involvement phase memiliki arahan menambah ketersediaan fasilitas serta melakukan dan memperluas kegiatan promosi.

- Pada development phase memiliki arahan menjalin kerjasama dengan investor.

- Pada consolidation phase memiliki arahan pelestarian kondisi lingkungan dan penambahan atraksi wisata serta penyelenggaraan event tertentu.

- Pada decline phase memiliki arahan memperbaiki fasilitas utama yang sudah beralih fungsi.

- Pada rejuvenation phase memiliki arahan perbaikan dan pengadaan atraksi wisata baru.

\section{DAFTAR PUSTAKA}

[1] Biro Perencanaan dan Keuangan Sekretariat Kementrian Pariwisata, "Laporan Akuntabilitas Kinerja Kementrian Pariwisata Tahun 2015,” Jakarta, 2016.

[2] Dinas Pariwisata Kabupaten Ponorogo, "Potensi Pariwisata Kabupaten Ponorogo Tahun 2016,” Ponorogo, 2016.

[3] PERDA Kabupaten Ponorogo No. 1 Th. 2012 tentang Rencana Tata Ruang Wilayah Kabupaten Ponorogo Th. 2012-2032. Ponorogo.

[4] PERDA Kabupaten Ponorogo No. 4 Th. 2016 tentang Rencana Pembangunan Jangka Menengah Daerah Kabupaten Ponorogo Th. 2016-2021. 2016.

[5] C. Faradilla, "Pengembangan pariwisata berbasis masyarakat lokal: studi tentang pengembangan pariwisata di Kabupaten Ponorogo,” Universitas Brawijaya, 2010.

[6] BAPPEDA Kabupaten Ponorogo, "Laporan Akhir Kajian RIPPDA Kabupaten Ponorogo Tahun 2016,” Ponorogo, 2016.

[7] R. Butler, The tourism area life cycle, Vol. 1. Clevedon: Multilingual Matters, 2006. 